\title{
INTENSIVE TOURIST-RELATED URBANISATION IMPACTS ON A MOUNTAIN VILLAGE: THE CASE STUDY OF VELKÁ LOMNICA IN SLOVAKIA
}

\section{Lucia Petrikovičová ${ }^{1}$ (D) Alfred Krogmann ${ }^{1}$ (D) Dana Fialová ${ }^{2}$ (D) Andrej Svorad ${ }^{3}$ (iD}

${ }^{1}$ Faculty of Natural Sciences Department of Geography and Regional Development Constantine The Philosopher University in Nitra

Tr. A. Hlinku 1, 94974 Nitra: Slovakia

e-mails: Ipetrikovicova@ukf.sk・akrogmann@ukf.sk

${ }^{2}$ Faculty of Science, Department of Social Geography and Regional Development

Charles University in Prague

Albertov 6, 12800 Praha 2: Czech Republic

e-mail: danafi@natur.cuni.cz

${ }^{3}$ Unaffiliated researcher

e-mail: andrej.svorad0@gmail.com

\begin{abstract}
A key feature of contemporary tourism is massive investment on the part of developers in tourism-related urbanisation, with this made most manifest in the construction of recreational apartment houses, and the expansion of ski slopes and golf courses. For obvious reasons, such activities are directed at traditional centres of tourism, which respond to the current trend towards hedonism present in society. However, major development activity has also taken place in municipalities in which tourism only began to play its more significant part once social and political transformation had already occurred. An example is the Slovak municipality of Vel'ká Lomnica, a village in which golf-course construction has initiated large-scale development projects. The aim of the work described in this paper was precisely to address this example in assessing the impact of tourism-related urbanisation on the municipality in question.
\end{abstract}

\section{Key words}

tourism-related urbanisation • impact of tourism • Vel'ká Lomnica municipality • Slovakia

\section{Introduction}

This text reports on the issue of tourism-related urbanisation as this interferes with rural communities and produces marked changes in their character from the physical point of view, as well as shaping attitudes to the phenomenon within the local population. Tourism 
is an economic sector of long tradition, but one whose intensity has increased greatly in recent years. This is all the more so in areas providing a "background" to tourist attractions, given that, for reasons related to legal protection enjoyed (for example in National Parks or Reserves), the latter cannot by themselves extend their capacities as regards accommodation and other infrastructure that visitors and tourists typically require.

Areas newly affected by these kinds of change have usually been rural in nature, with a prevalent agricultural function, and an initial capacity to provide only minimal services for visitors.

An enormous increase in areas under these new kinds of uses thus took place around the turn of the millennium, especially in countries that had been undergoing political, social and economic change from the 1990s onwards. It was in this transformation period - in the Central and Eastern European (CEE) countries - that processes of privatisation and the restitution of property took place. In rural communities there was a return of the communist-era Collectives and State Farms to (the heirs of) their original owners. Often, however, due to the disrupted property relations and the nature of the relationship with the land, the beneficiaries of this process lack necessary knowledge and/or are unwilling to manage farms. This leaves selling as their best option, and that has denoted opportunity for developers, very often of foreign origin, who can rapidly raise the value of land acquired by building tourist infrastructure upon it.

To exemplify this kind of process in Slovakia - and most likely in the CEE countries in general - this paper makes reference to the village of Vel'ká Lomnica, which is located in the immediate hinterland of the High Tatra Mountains. Indeed, this village may be regarded as the most important destination for tourists anywhere in Slovakia, and one which plays an important role in international travel also, especially for tourists coming from neighbouring Poland and the Czech Republic.
Field surveys and maps provided the basis for the analysis of land-use changes presented here. However, this was augmented by a successful effort to obtain the views of residents on the newly-emerging situation of tourism-related urbanisation, which is to say that a questionnaire survey was conducted. On the basis of facts established in these ways, it proved possible, not only to characterise the phenomenon of tourism-related urbanisation in a village well-suited to serving as a model, but also in general to draw attention to the phenomenon in question and its relevance.

The aim of the work detailed here has thus been to draw on a specific example in order to highlight and discuss the transformation of rural communities that occurs - and is actually occurring - as tourist infrastructure is increasingly put in place in rural (mountainous) areas, as well as the way this is all perceived by residents.

\section{Theoretical background}

Tourist-related urbanisation (Liszewski 1991) is understood as a manifestation of tourism, which significantly changes a still-rural environment in a manner that must be considered to have negative impacts. Certainly, the process entails a change in the type of residence to those mostly focused on tourism; but there is also change in the physical environment, with the needs of tourists also bringing about a transformation of functions. While residence of this type in relation to tourism is inclined to attract more tourists (and have its certain upsides for permanent residents too, given a wider range of recreational activities in our case in connection with a mountainous environment), the phenomenon may - as suggested above - prove negative for indigenous inhabitants and their buildings. This particularly reflects excessive construction in the settlements involved, with the consequence that a number of problems arise (Kadlecová \& Fialová 2012; Horáková \& Fialová 2014).

Thus, while tourism can obviously represent a very important resource for a local 
economy - especially where the potential inherent in the given place is maximised, planning not pursued with considerable wisdom can end up having a very bad impact on the local economy and its cultural and natural resources. This makes it very important that tourist-related urbanisation should be analysed carefully (Hamzah \& Noor 2003). Rural areas prove particularly sensitive in this regard, and increased mobility means that tourism can "delocalise" (Giddens 2000) or "deterritorialise" their environment (Tomlinson 1999). The space there is in effect being "consumed", not only by local residents and other interest groups (in this case tourists), but also by visitors who reside permanently or in parallel in another area, which is often quite different economically, environmentally and socio-culturally. There is a mutual relationship between the traditional categories of "guest" and "host" (Smith 1989) that can be described by reference to social-exchange theories (Ap 1990). Guests usually look for authenticity of the environment (Burns 1999; Meethan 2001), but they often require services (almost by definition) unavailable in that environment. That can tempt "hosts" into rebalancing their "own" environment, bearing in mind the desirability as a form (or the only form) by which they can achieve further development (Horáková \& Fialová 2014).

In our case study it is Vel'ká Lomnica in Slovakia that became a tourist destination, and its development can reflect a theoretical concept involving the so-called life cycle of the tourist destination (Butler 1980). In real life, this means an increase in bed capacity, numbers of tourists and income (as was presumably desired), but also changes over times in types of tourist, and in the attitudes of residents (Doxey 1975). In the present study, we will focus in on the increase in bed capacity (due to the construction of recreational apartment blocks), as well as the attitudes of residents to ongoing changes.

Needless to say, rural areas transform much more markedly where they are at the same time of interest to tourists, or in close proximity to areas that are. Changes take on great intensity, also in terms the economic and social environment that is put in place. Slovakia as such has a society undergoing a post-communist transformation (the similar changes in the neighbouring Czechia have gained adequate presentation in Perlín (2009), while the story of Slovakia - as the other state to emerge from the former Czechoslovakia - is recounted by Žoncová (2018)).

The rural space in these and other Central and Eastern European countries has been forced to respond to restitution, privatisation, disintegration, the restoration of tiers of local and regional government, changes in ownership structure and reformed agricultural policy. In response to societal changes, local government had first to seek mechanisms and strategies ensuring even the survival of rural communities. More recently, it has also been necessary to address issues of economic development. The result is a change in the role of local government, which is "business-oriented" (Hall \& Jenkins 1995). It thus responds to pressures to create new jobs and investment incentives and opportunities which mainly originate abroad, due to a lack of domestic capital (Horáková \& Fialová 2014). A means of promoting business activity is obviously tourism, which in turn depends entirely on the construction of relevant infrastructure, first and foremost facilities as regards accommodation.

Besides collective lodgings or private accommodation, at the end of the 20th century in post-communist countries the new phenomenon of the holiday apartment block made its appearance. From one point of view, these can be compared with traditional second homes, huts/chalets and holiday cottages, which are objects of private recreation in private ownership. On the other hand - and especially from a physical point of view, these are in the nature of urban residential buildings intended for permanent housing. Individual apartments within them are usually sold by a developer to individual owners to meet their own recreational needs, or potentially for further lease. In recent years, the latter kind of activity has of course been facilitated 
by the Internet platform Airbnb (Gurran \& Phibbs 2012; Guttentag 2015; Šolcová \& Dysková 2018). This is not then shared living in the true sense, but rather a kind of distorted version of business involving accommodation services.

In any case, the construction of such blocks of recreational apartments in the village has done much to intensify the impact of classical tourism. At the same time similarity of construction presents more specific problems given the typical way of building this type of recreational second home. Uncontrolled construction of new apartment buildings of this kind may have a negative impact on the surrounding natural environment and the economic situation of the affected municipalities, and may ultimately affect the community atmosphere in a village (Kadlecová 2010).

One of the most-discussed issues is the disruption of the landscape in affected locations. Very large complexes of apartment houses are often built in an ambitious architectural style, clearly disrupting the natural urban concepts of the villages, and transforming mountain settlements of traditional character into an urban form. This is related to the loss of the genius loci (Steinecke 2006; Zelenka 2008;), in which the original tourist attractiveness of these localities and their backgrounds is considered to originate.

The construction of new apartment blocks can dubiously be said to increase capacity as regards accommodation, but use is characterised by marked seasonal fluctuations, and thus contributes to increasing seasonality of use of mountain-tourism destinations. On the one hand, a high level of occupation leads to overcrowding of municipalities during the main tourist season, with all the associated burdening of municipalities' technical infrastructure. On the other hand, the perceptions of residents of these communities as regards the emergence of the so-called "dead Houses" or "ghost houses" are negative, with what are involved here being effectively abandoned, empty houses during the off-peak season and away from weekends.
Furthermore, it is not unusual for the complexes in question to become the so-called "gated communities" (Brabec 2014) - a fact that only enhances problems at times of full use or "abandonment" alike.

More specifically, negative effects for the municipal budget can be said to entail a combination of increased demand for maintenance around the property and roads, as well as waste management, in the face of negligible income flowing into the municipal budget. For state tax policy does not ensure sufficient involvement of holiday-home owners in local tax, and in the tax system of each given municipality. Owners of such apartments do not report a permanent residence status, while "temporary" residents do not yield funds for the community and its budget. At the same time, it is typical for municipalities not to receive recreational fees from beds within these apartments (no matter what way they are actually used), unlike in the case of commercial accommodation facilities of more "legible" status (i.e. hotels, guesthouses, etc.) (Kadlecová \& Fialová 2012).

\section{Data and methods}

To analyse changes in the area put to recreational use in the context of tourism-related urbanisation at the selected location, use has also been made of secondary objective data - i.e. the areas under given types of use that be compared readily for the period before new construction (2003) and currently (in 2017). The sizes of the areas in question were identified by reference to an orthophotomap, and then verified by field research. By creating map layouts we received information on the locations of - and overall areas accounted for by - 8 groups of landscape elements. The evaluation and mapping of the current landscape structure (CLS) was based on these, albeit as further sub-divided by us. The legend was created by combining Corine Land Cover classes (Ružička 2000), with account also taken of the human-geographic and landscape-ecological procedures for assessing changes in landscape (land use) 
(Šolcová 2012), as well as landscape structure in line with LANDEP methodology.

In the field of theoretical research, LANDEP works to assess and compare the optimal use of the landscape's ecological characteristics, and to create conditions that help ensure consistency between human beings and the landscape. In land-use planning, LANDEP was projected into a simplified form of social and ecological assessment of territory (EHU). It is a wide-ranging synthesis of knowledge about the potential for ecologically-optimal land use, in line with the purposeful creation of conditions, the preservation and development of healthy populations of organisms and human beings, and the development of human society (Ružička 1999; Forman \& Godron 1986).

The impacts of tourism were here verified in the field, with the support of orthophotos and contour maps of the state map work of the SR. By comparing the secondary landscape structure (SLS) in the circumstances of the time horizons selected, we have characterised the changes occurring among the groups of landscape elements in the territory delineated. At this stage, we focused on the mapping of the current landscape structure (CLS), prior to the results being set against map data at a scale of 1:10,000 or 1:25,000. Traditional methods of obtaining information about CLS are based on an analysis of various topographic and thematic maps, aerial photographs and field surveys. Part of the field research entailed the obtainment of photo documentation.

To illustrate the situation, it is also appropriate that use be made of subjective, primary data, which gives an idea of how tourism-related urbanisation is perceived by the local population (Kadlecová \& Fialová 2010). For this purpose, 259 randomly-addressed respondents were interviewed. They were determined by position taken in respect of their village, as regards the economy (e.g. whether the above phenomenon represents a source of funding for the municipality, whether it addresses unemployment issues), the socio-cultural sphere (e.g. impact on resident integrity), and the environmental impact of tourism-related urbanisation (e.g., increase in traffic, noise and an increase in the generation of waste). We also took an interest in the general attitude displayed towards these new changes. Evaluation here made use of the classification based on the irritancy index after Doxey (1975). Hypotheses were advanced in regard to the relationship between respondents' overall attitudes to tourism-related urbanisation and their characteristics (in terms of age, education, period of time spent in the village, and economic activity related to tourism). We used the Chi-square test $(\alpha=0.05)$ in qualitative analysis to test for the existence of a statistically-significant correlation between the observed features. We tested hypotheses regarding the independence of the observed characters at the selected level. After identifying a statistically-significant dependent relationship, we measured the intensity (strength) of that statistical relationship using the contingency coefficient (C).

\section{Study area}

The territory under consideration here is in the northern part of Slovakia (Fig. 1). It falls within the district of Kežmarok, which is in turn part of Prešov region.

To the east this is area borders with Huncovce, to the north with Stará Lesná and Vysoké Tatry (the cadastral area of Tatranská Lomnica), to the west with Matejovce and Mlynica, and to the south with Žakovce. The municipality itself covers 1912 ha, while its 2018 population is 4609 . This makes this one of the large municipalities in the area, achieving a population density of 235.04 inhabitants per $\mathrm{km}^{2}$. The study area has excellent access to the D1 highway, which passes through just $4 \mathrm{~km}$ to the south. The road guarantees the village's transport accessibility in terms of the whole of Slovakia, and even internationally. Michniak (2016) regards this fact as of major importance in accounting for the value of tourism here. Vel'ká Lomnica is accessed via routes I/ 66 in the 


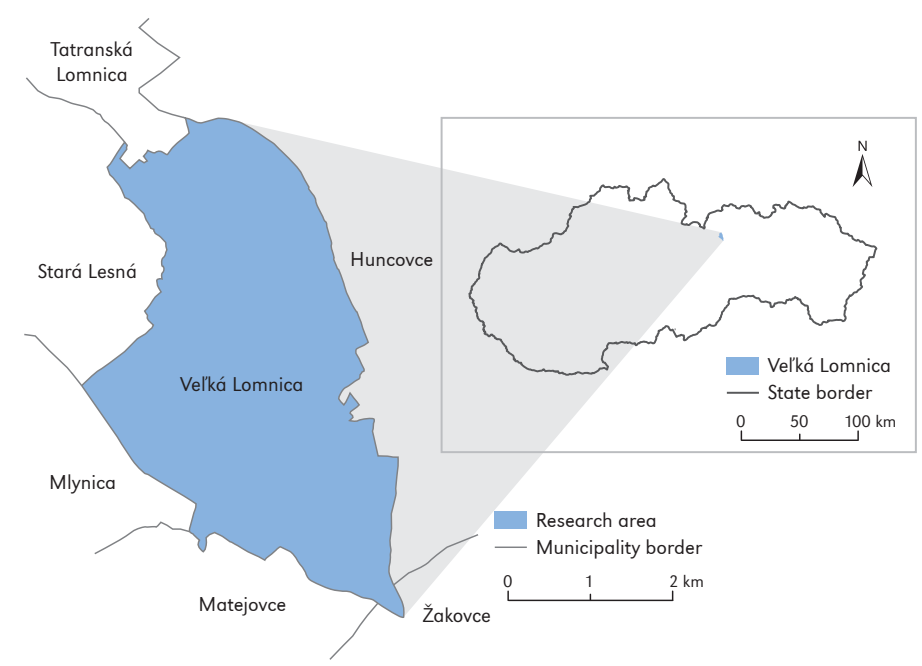

Figure 1. The location of Vel'ká Lomnica

Source: Elaborated in 2018 by ArcMap 10.1.

direction of Poprad - Kežmarok, and II / 540 in the direction of Vel'ká Lomnica - Tatranská Lomnica. The village is thus an important crossroads between the towns of Poprad, Kežmarok and Vysoké Tatry. The whole area falls within the wider Tatra Mountain region of major importance to tourism. More specifically, these are the Vysoké Tatry (High Tatra Mountains) - and they form Slovakia's most-important tourist region (Dubcová et al. 2008).

\section{Tourism in Vel'ká Lomnica}

Tourism in the village is based on several pillars. The key one is exogenous - the aforementioned proximity and very good access to the village core of the Tatra region tourism sector, provided by the High Tatra mountains. These, together with Bratislava and the spa in Piestany, represent the greatest attractors of tourists to Slovakia (Baláž \& Mitsutake 1998). The importance of the High Tatras in the context of Slovakia's tourism can be documented by shares of the total resource of beds for tourists in Slovakia (10\%), the share of the number of residents (13\%) and the share of the total number of overnight stays (14\%).
The Vysoké Tatry Mts. have options guaranteeing year-round tourism and winter sports (the distance between Vel'ká Lomnica and the ski slopes in Tatranská Lomnica is 4 km). Even in the communist era, this provided a basis for the arrival of tourists in the village. As private business was restricted during that period, tourist infrastructure remained very limited, both qualitatively and quantitatively, to a few state facilities. In addition, there was only a sign of (state-tolerated) private business, in the form of rented rooms in family houses.

Political and social changes initiated in 1989 also found their reflection in the municipality's tourism. First there was the return of state-expropriated land to its original owners. Many of these had lost touch with agriculture, and also lacked the funds to purchase necessary equipment. This accounted for a tendency for reinstated land to be sold to developers. They used the potential position of the village (the aforementioned proximity of the Vysoké Tatry Mts.), and initiated a massive development of recreational urbanisation. This is represented by areallyintensive projects such as, the golf course. According to Fialová (2015) and Sláma et al. 
(2018), golf does contribute to increasing demand in the area. The course's construction (1999-2007) was followed up by the building of a complex of apartment houses (20072010). This was supported by the geothermal resources present in the village (so far used solely to heat apartment houses).

From a general point of view, the village serves mainly as a base for tourist attractions located outside the area (i.e. the Vysoké Tatry, Pieniny and Slovenský raj Mountains, as well as the Tatralandia Aquapark near Poprad). This fact is reflected in bed capacity, which reached 1608 in 2018, with the number of inhabitants (4,821 as of 1 January 2018) being the value of the tourism index of 33.35; and in 2017 with 26,656 overnight stays in the village by 9,888 visitors. The average length of a stay thus stood at just 2.69 days.

Tourist urbanization and its impact on the landscape of Vel'ká Lomnica

Table 1 shows the areas of selected landscape elements and their shares in the total area of the village of Vel'ká Lomnica. Calculations make it clear that the area of accommodation establishments increased by nearly 3 ha, while the area given over to parking rose by $5 \mathrm{ha}$, this making the dynamic present in the area abundantly clear.

For research purposes, recreation urbanization is just an interesting component area of residential elements and recreational facilities overall. In 2003, this group accounted for an area of 96.59 ha, of more than 5\% of the total area of land in that year. Covering least ground were the groups of water elements and transport elements.

In 2017, the group of elements comprising agricultural crops was again the most represented, accounting for $59.02 \%$ of the total area of the municipality. However, the second-greatest coverage was achieved by the group of elements of settlement plus recreational areas. The 2017 area in this category was $277.12 \mathrm{ha}$, or $14.5 \%$ of the investigated area overall. Meadows and pastures then accounted for $10.06 \%$ of the total area, with still-more-limited representation of forest, technical, transport and water elements.

Analysis by reference to cover ascribable to these groups in 2003 and 2017 (Fig. 2) made clear certain trends characterising the village of Vel'ká Lomnica even over the relatively short period of 13 years. It was the groups including agricultural crops and forest that changed most, with the share of the former decreasing more than 10\% (Tab. 2). As agricultural crops were mostly lost to residential elements and recreational areas, the change reflects the aforementioned touristrelated urbanisation, which is in fact very manifest in Vel'ká Lomnica. For its part, the group comprising residential elements and

Table 1. Selected landscape elements of Vel'ká Lomnica municipality (2003 and 2017)

\begin{tabular}{|c|c|c|c|c|}
\hline \multirow{2}{*}{ Landscape element } & \multicolumn{2}{|c|}{2003} & \multicolumn{2}{|c|}{2017} \\
\hline & ha & $\%$ & ha & $\%$ \\
\hline Accommodation & 3.63 & 0.19 & 6.01 & 0.31 \\
\hline Roads & 4.37 & 0.23 & 4.91 & 0.26 \\
\hline Car parks and other parking areas & 3.03 & 0.16 & 7.93 & 0.41 \\
\hline Coniferous forest & 24.20 & 1.26 & 24.20 & 1.26 \\
\hline Urban green space & 33.70 & 1.76 & 25.89 & 1.35 \\
\hline Railway & 0.65 & 0.03 & 0.65 & 0.03 \\
\hline Other & 1842.42 & 93.36 & 1842.41 & 93.36 \\
\hline Overall & 1912.00 & 100.00 & 1912.00 & 100.00 \\
\hline
\end{tabular}

Source: Own field research, 2017. 
Table 2. Groups of landscape elements in Vel'ká Lomnica

\begin{tabular}{|l|r|r|r|r|}
\hline \multirow{2}{*}{ Groups of landscape elements } & \multicolumn{2}{|c|}{2003} & \multicolumn{2}{c|}{2017} \\
\cline { 2 - 5 } & \multicolumn{1}{|c|}{$\mathrm{m}^{2}$} & \multicolumn{1}{c|}{$\%$} & \multicolumn{1}{c|}{$\mathrm{m}^{2}$} & \multicolumn{1}{c|}{$\%$} \\
\hline Group of permanent grassland (pastures) & $1,922,489.46$ & 10.06 & $1,922,489.46$ & 10.06 \\
Group of agricultural crops & $13,483,445.27$ & 70.57 & $11,276,535.62$ & 59.02 \\
Group of transport elements & $197,177.88$ & 1.03 & $304,310.56$ & 1.59 \\
Group of water elements & $78,732.54$ & 0.41 & $103,446.05$ & 0.54 \\
Group of technical elements & $677,319.25$ & 3.54 & $948,185.85$ & 4.96 \\
Group of forest elements & $178,224,212$ & 9.33 & $1,781,180.19$ & 9.32 \\
Group of settlement elements & $965,983.49$ & 5.06 & $2,771,242.27$ & 14.50 \\
and recreational areas & & & & 100.00 \\
\hline Overall & $19,107,390.00$ & 100.00 & $19,107,390.00$ & 100.00 \\
\hline
\end{tabular}

Source: Own field research, 2017.

Secondary landscape structure (SLS)

2003

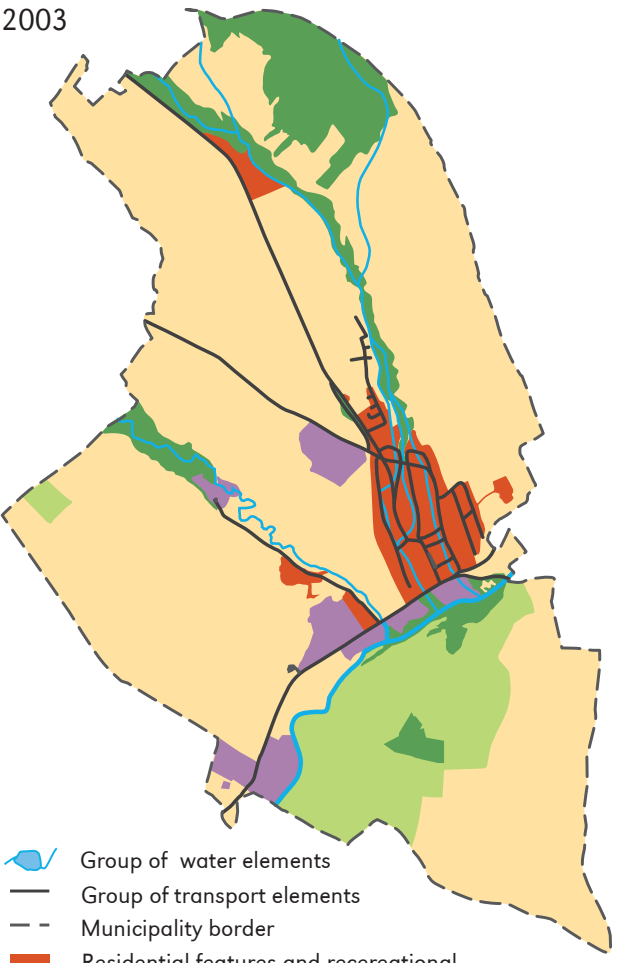

Residential features and recereational

Group of technical elements

Agricultural areas

Pastures

Forests
Current landscape structure (CLS)

2017

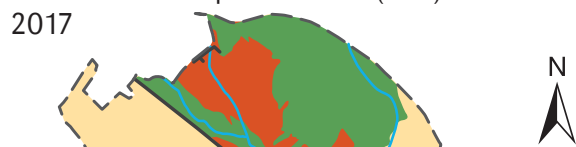

$\stackrel{N}{\Lambda}$

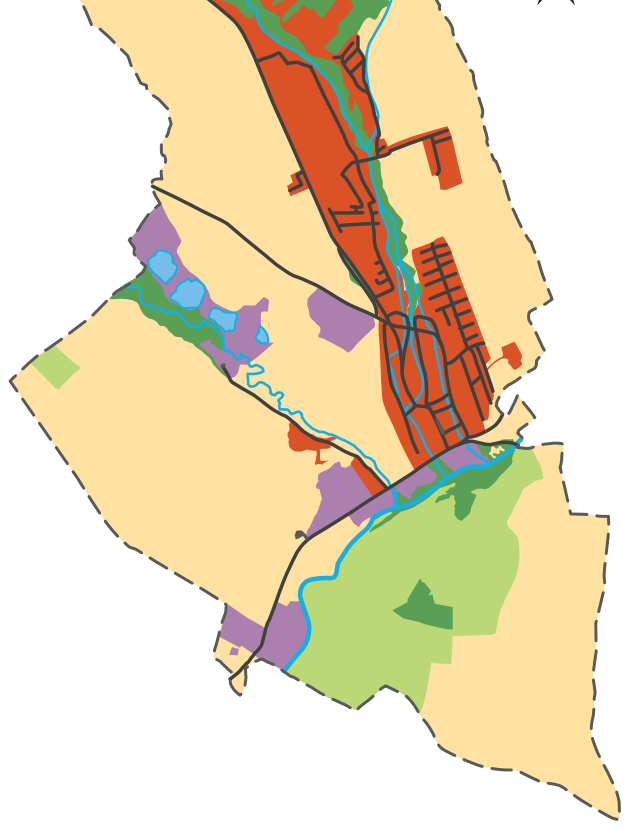

0 $1 \mathrm{~km}$

Figure 2. Landscape structure of Vel'ká Lomnica (SLS and CLS) in 2003 and 2017

Source: Elaborated in 2018, by ArcMap 10.1. 
recreational areas increased in area from $5.06 \%$ of the whole municipality to $14.5 \%$.

In 2003, the dominant group elements remained agricultural crops, still accounting for $70.57 \%$ of the total land area of Vel'ká Lomnica. The second largest group comprised meadows and pastures, especially in the southern part of the village. Similarly, forest elements were still very much present, especially in the northern part of the municipality and along the river.

Group growth in this case is up to $187 \%$. The change is the result of several factors. The decline in the group comprising agricultural crops has also manifested itself in a $54 \%$ increase in area of transport land, itself a response to the demands of tourism. By 2017, the group of water elements had also shown an increase, reflecting the creation of waters in the newly-built industrial area in the village's western part. Change, albeit minimal, was observed for forest elements, which were somewhat reduced in size. The share of the total area accounted for by forest was shown to decrease, mainly thanks to further growth in the area of transport-related land.

The increase in the area accounted for by the group of settlement and recreation areas to such an extent and in such short time as in the village of Vel'ká Lomnica requires special attention, and a more complex analysis of how growth developed. The main factor that has affected this change is tourismrelated urbanisation.

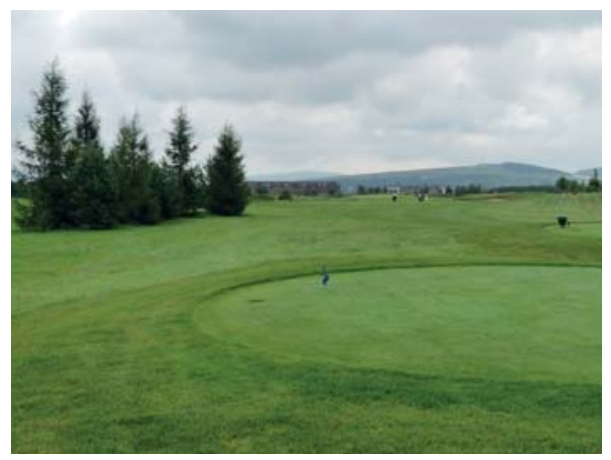

Figure 3. Golf Area in Vel'ká Lomnica (2018)
Most probably, this change was influenced by the completion of the Black Stork Golf Resort in 2007 (Fig. 3). Subsequently, the village was gradually built up between the original intravilan and the golf resort. There was then a gradual development of the accommodation-related infrastructure, as divided into two groups. The first group comprises apartment blocks. The inspiration to large investment companies offered by alpine projects. and their efforts to achieve large, simple outcomes were what led to the construction of large complexes of apartment blocks within Vel'ká Lomnica (Fig. 4).

It is quite logical that the construction of such large complexes of accommodation facilities will not be carried out directly in the resorts of Tatranská Lomnica or Štrbské Pleso. However, Vel'ká Lomnica does include a large complex of apartment houses - Tatragolf, consisting of 11 three-storey buildings of total possible capacity equal to 900 beds. The investor was interested to build a water park near the apartment blocks, but that plan was rejected subsequently by the municipality. At present, the aquapark is operated despite permission of the municipality being absent, circumventing problems by building a socalled temporary aquapark (it deflates when not in service). It should be recalled how the complexes of apartment blocks are not especially interesting from the point of view of their contribution to the municipality's budget overall, since visitors coming to stay in such

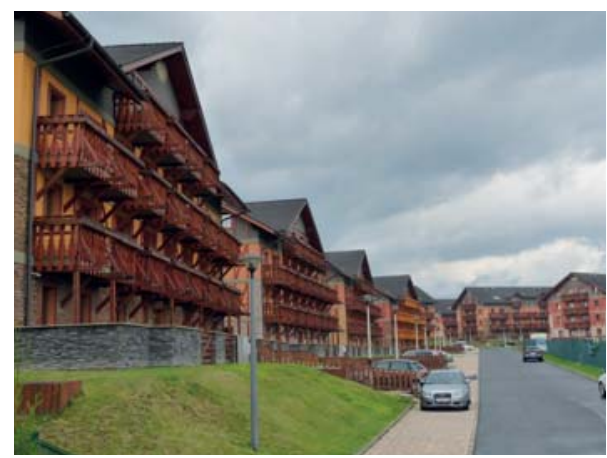

Figure 4. Apartment blocks in Vel'ká Lomnica (2018) 
places do not pay the accommodation tax, which is to be paid by each accommodation operator on behalf of guests. This reflects the way investors offer a rental service for individual apartments, ultimately denoting zero income into the general budget. This just exemplifies the "uncontrolled" nature of the tourism-related urbanisation taking place within the area of Vel'ká Lomnica.

The second group of accommodation facilities, built or still under construction, involves individually-owned buildings serving recreational purposes (Fgs. 5, 6). The building of ever-larger and ever-more-imposing homes of this kind is a new trend in the villages of the High Tatra Mountain hinterland. Even in Vel'ká Lomnica, this trend is visible in full, as is made clear by the character of the road leading directly to the golf course. Here there are a number of large, individually-owned

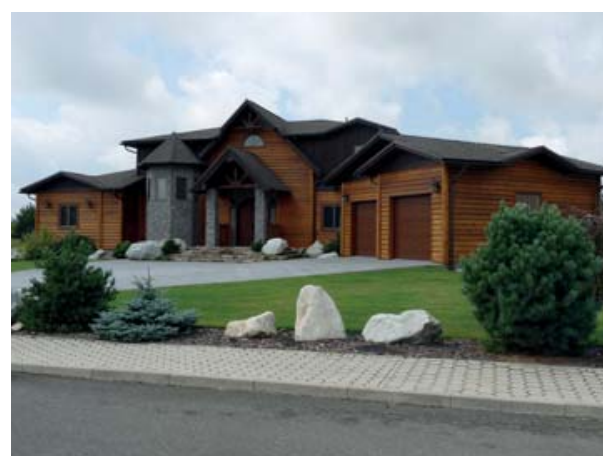

Figure 5. Individual homes in Vel'ká Lomnica serving recreational functions (2018)

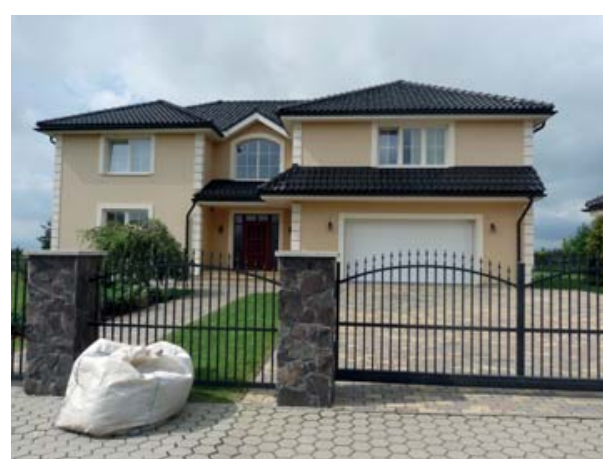

Figure 6. Individual houses in Vel'ká Lomnica serving recreational functions (2018) residences serving recreational functions and also boasting large gardens. These recreational objects can be perceived as status symbols manifesting luxury, and thus telling those who see them about the owners. Actual use of these buildings in the course of a year is sporadic at best. The overall consequence here is the emergence of a basically depopulated zone within the village, but entirely segregated from the parts occupied clasically.

\section{Residents' perception of tourism-related urbanisation in Vel'ká Lomnica}

When it comes to the changes unregulated tourism-related urbanisation can give rise to, Vel'ká Lomnica offers a very significant example. One way of assessing the burdensome nature of this development involves determining attitudes among local inhabitants, who are key stakeholders in the area, yet are often in fact marginalised. Their views should therefore be defended by local government, yet unity of purpose between these players is not always evident (Horáková \& Fialová 2014). This was among the factors dictating the pursuit of questionnaire-based surveying in Vel'ká Lomnica, which gave rise to answers from 259 inhabitants aged 18 and over. In more detail, respondents are as characterised in Figure 7. Middle-aged women proved most responsive of all, as the diagram makes clear.

Positive or rather positive emotions (ranging from euphoria to apathy) are perceived in regard to the economic and socio-cultural impacts that tourism-related urbanisation have had. This would tend to sum up the general attitude towards change to be noted in the village, and the interpretation is the straightforward one that the same process as has entailed tourism-driven urbanisation has brought with it employment opportunities, greater earnings (or earnings in general), and a raising of living standards. Where assessment of the socio-cultural impact is concerned, a major influence has been exerted by the siting of the new leisure development 


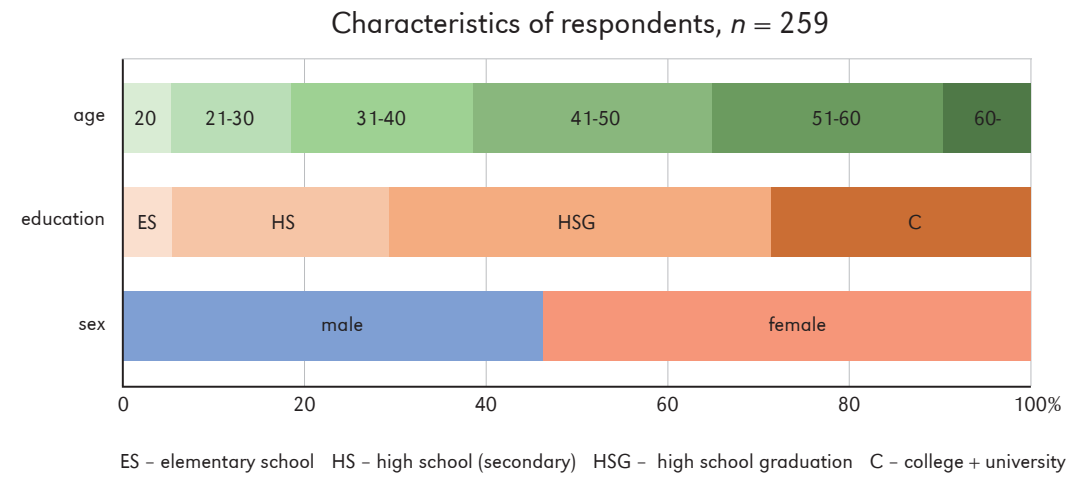

Figure 7. The structure of the group of respondents

Source: Own field research, 2017, $n=259$.

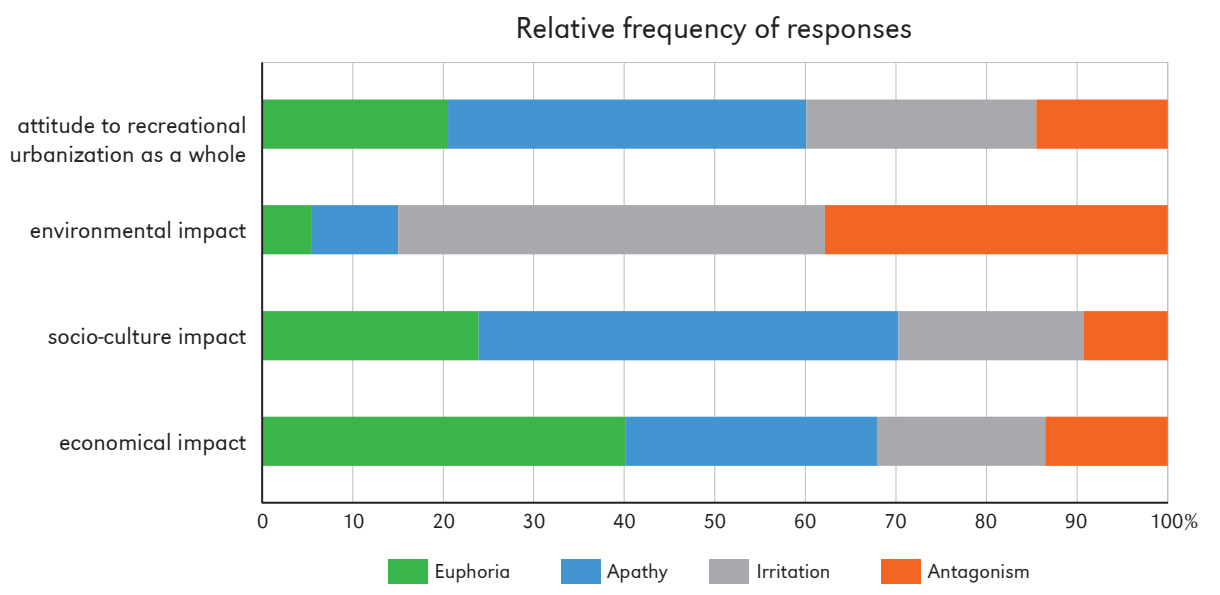

Figure 8. Attitudes of respondents (or selected residents) to manifestations of tourism-related urbanisation in the village

Source: Own field research, 2017, $n=259$.

(in fact separated from the village), at which tourists and residents do come into contact with the facility and with each other.

Equally, respondents are aware of negatives accruing from urbanisation for the sake of tourism that can far outweigh the positives (Fig. 8). The question revolves around future construction and expansion in the context of local tourist-related exploitation of geothermal resources. A study from the Czechia, i.e. from a similar economic and socio-cultural environment, confirmed that the more apartment blocks present in a village, and the longer they are in operation, the more people accept that there are negatives (minimum income from taxes, a grey economy associated with other illegal leasing, and the need to manage new communications infrastructure with no extra revenue raised, as a reflection of the fact that legal entities often managing buildings are seated outside the municipality, and do not therefore pay income tax there) (Kadlecová \& Fialová 2010, 2012).

At the opposite pole of opinion, however, the environmental impact assessments, where $40 \%$ of respondents expressed an antagonistic attitude and over 45\% 
of disgust. This can be mainly due to the inaccessibility of the golf course (Fialová 2015), the significant consumption of water required for its maintenance (Fialová 2017; Hof 2011), the architectural concepts underpinning apartment houses (sizes of buildings not corresponding with local-level development and the increasingly urban character of the village), the increased paved area, and the burdening of the landscape towards the highway and Tatranská Lomnica (increased use and noise). Thus, in general, visual and functional disturbance of the landscape of the village is involved here.

To determine the relationship between the performance characteristics of respondents and their attitudes towards tourism-related urbanisation, a null was hypothesis. Based on the Chi-square test, we have found:

1. no statistical significance to the relationship between the level of education of respondents and their attitude to tourism-related urbanisation;

2. a moderately strong relationship between attitude and age, given a contingency coefficient value reaching $c=0.566$;

3. a relationship between the length of time spent in the village and the attitude, with the coefficient here attaining a value of $c=0.614$;

4. a strongest relationship between economic activity of a respondent in tourism and the attitude manifested towards tourismrelated urbanisation (with $c=0.811$ ) - thus those who gain economically from urbanisation related to tourism are more likely to perceive the development positively.

We can therefore sum up by saying that attitudes "pro" tend to be more of a positive spectrum of answers. This may partly document the beginning of a dualisation of the local community, i.e. a division of the population into those who benefit economically from the changes in the village, and those who merely have to endure the impacts of the emerging tourism. This is mainly a matter of the "tourist inflation" mentioned by certain respondents.

\section{Conclusion}

Changes in the socio-economic and political environment of Slovakia after 1989 affected the economy and the way of life of the population. In regions attractive to tourists, and in their immediate vicinity land has become a commodity. That has attracted developers whose business activities here have mushroomed, for example taking the form of golfcourse construction or the building and sale of apartment complexes on parcels of land purchased from people returning after 1989.

Such a scheme has also been applied in the municipality of Vel'ká Lomnica. Over the relatively short period of 13 years, the development activities referred to have increased the proportion of elements of residential buildings and tourist areas significantly - by $187 \%$. To maximise their profits, developers build two-floor houses, which denote the introduction into a traditional rural environment of elements of urban architecture. Such an intervention in the use of the landscape and its image is even more serious in the area concerned, as it can negatively affect the position of the Tatra landscape and the Tatras as a commonlyused symbol of Slovakia and the Slovaks that even finds its reflection in the Slovak national anthem.

A survey conducted on the perception of tourist urbanisation in the municipality of Vel'ká Lomnica, among its residents (a sample of 259) failed to demonstrate a negative perception of the economic and sociocultural impacts. It is possible to justify the isolation of zones with a tourist function (the golf course and accommodation complexes) from residential areas. The point of contact between residents and tourists can thus be limited to shopping in the shopping centre, which is located on the boundary between the two zones. However, responses already reveal signs of a dualisation of society arising, with a division of the population into those who benefit from tourism and those who will suffer because of it (via 
increases in the prices of goods, services and real estate). It is possible to assume that a further wave of tourist-related urbanisation, which may further split the community, might be attributable to a more significant touristrelated exploitation of geothermal resources.

In contrast, the environmental impacts of tourist urbanisation for residents are predominantly negative. This is mainly related to the visual and functional disruption of the landscape, and the overall environment in which residents live.

\section{Acknowledgments}

This work was supported by the Slovak Research and Development Agency under the Contract no. APVV-18-0185. Also, the study was carried out thanks to the international research project: Social and Innovative Platform on Cultural Tourism and its Potential towards Deepening Europeanisation (SPOT, www.SPOTprojectH2020.eu) funded by the European Commission H2020 Programme under Grant Agreement number: 870644.

Editors' note:

Unless otherwise stated, the sources of tables and figures are the authors', on the basis of their own research.

\section{References}

Ap J., 1990. Residents' perceptions research on the social impacts of tourism. Annals of Tourism Research, vol. 17, no. 4, pp. 610-616. https://doi.org/10.1016/0160-7383(90)90032-m

Baláž V., Mitsutake M., 1998. Japanese tourists in transition countries of Central Europe: Present behaviour and future trends. Tourism Management, vol. 19, no. 5, pp. 433-443. https://doi.org/10.1016/s0261-5177(98)00040-5

Brabec T., 2014. Gated communities as a symbol of a postmodern city: The case of Prague. Geografie. vol. 119, no. 3, pp. 278-298.

Burns P.M., 1999. An introduction to tourism and anthropology. London: Routledge.

Butler R.W., 1980. The concept of the tourist area life-cycle of evolution: Implications for management of resources. Canadian Geographer, vol. 24, no. 1, pp. 5-12. https://doi.org/10.1111/j.1541-0064.1980.tb00970.x

Doxey A., 1975. Causation theory of visitor-resident irritants: Methodology and research inference [in:] Sixth Annual Conference Proceedings,'The Impact of Tourism', San Diego, California pp. 195-198.

Drdoš J., 2004. Geoekológia a environmentalistika. I. čast'. Prešov: PU v Prešove.

Dubcová A., Lauko V., Tolmáči L., Cimra J., Kramáreková H., Krogmann A., Nemčíková M., Némethová J., Oremusová D., Gurňák D., Križan F., 2008. Geografia Slovenska. Nitra: Univerzita Konštantína Filozofa, Fakulta prírodných vied.

Fialová D., 2015. Golfová hrišstě - nový prvek v krajině. Geografické rozhledy, vol. 25, no. 2, pp. 24-25.

Fialová D., 2017. Turismus - enormní spotřebitel vody. Geografické rozhledy, vol. 27, no. 1, pp. 20-24.

Forman R., Godron M., 1986. Landscape ecology. New York: John Wiley.

Giddens A., 2000. Runaway world: How globalisation is reshaping our lives. New York: Routledge.

Gurran N., Phibbs P., 2017. When tourists move in: How should urban planners respond to Airbnb? Journal of the American Planning Association, vol. 83, no. 1, pp. 80-92. https://doi.org/10.1080/01944363.2016.1249011 
Guttentag D., 2015. Airbnb: Disruptive innovation and the rise of an informal tourism accommodation sector. Current Issues in Tourism, vol. 18, no. 12, pp. 1192-1217. https://doi.org/10.1080/13683500.2013.827159

Hall C.M., Jenkins J.M., 1995. Tourism and public policy. London: Routledge.

Hof A., 2011. Urban and tourist land use patterns and water consumption: Evidence from Mallorca, Balearic Islands. Land Use Policy, vol. 28, no. 4, pp. 792-804. https://doi.org/10.1016/j.landusepol.2011.01.007

Horáková H., Fialová D., 2014. Transformace venkova: Turismus jako forma rozvoje. Plzeň: Nakladatelství a vydavatelství Aleš Čeněk.

Kadlecová V., 2010. Apartmánové rekreační byty v horských lokalitách - moderní alternativa tradičních chat a chalup, nebo problém pro obec? Geografické rozhledy, vol. 20, no. 2, pp. 26-27.

Kadlecová V., Fialová D., 2010. Recreational housing, a phenomenon significantly affecting rural areas. Moravian Geographical Report, vol. 18, no. 1, pp. 38-44.

Kadlecová V., Fialová D., 2012. Timesharing a apartmánové byty. Urbanismus a územní rozvoj, vol. 15, no. 1, pp. 20-25.

Liszewski S., 1991. Przemiany przestrzeni wiejskiej w Polsce w ostatnim czterdziestoleciu. Przyczyny skutki - formy [in:] S. Liszewski (ed.), Przemiany przestrzeni wiejskiej w Polsce i we Francji pod wpływem urbanizacji i turystyki, Acta Universitatis Lodziensis, Acta Universitatis Lodziensis, Folia Geographica, 14, Łódź: Wydawnictwa Uniwersytetu Łódzkiego, pp. 7-19.

Meethan K., 2001. Tourism in global society: Place, culture, consumption. New York: Palgrave.

Michniak D., 2016. Role of railway transport in tourism: Selected problems and examples in Slovakia. Quaestiones Geographicae, vol. 35, no. 4, pp.107-120. https://doi.org/10.1515/quageo-2016-0039

Perlín R., 2009. Dvacet let proměn českého venkova. Geografické rozhledy, vol. 19, no. 2, pp. 24-27.

Ružička M., 1999. Metodika LANDEP a jej uplatnenie v krajinnoekologickom výskumea praxi. Životné prostredie, vol. 33, no. 1, pp. 5-10.

Ružička M., 2000. Krajinnoekologické plánovanie - LANDEP I: (Systémový prístupv krajinnej ekológii). Nitra: Biosféra.

Sláma J., Bystřický V., Štych P., Fialová D., Svobodová L., Kvítek T., 2018. Golf courses: New phenomena in the landscape of the Czech Republic after 1990. Land Use Policy, vol. 78, pp. 430-456. https://doi.org/10.1016/j.landusepol.2018.07.001

Smith V.L. (ed.), 1989. Hosts and guests: The anthropology of tourism. Philadelphia: University of Pensylvania Press.

Steinecke A., 2006. Tourismus: Eine geographische Einführung. Braunschweig: Westermann.

Šolcová L., 2012. Vývoj krajiny s disperzným typom osídlenia v Novobanskej štálovej oblasti. Nitra: Univerzita Konštantína Filozofa, Fakulta prírodných vied.

Šolcová L., Dysková S., 2018. Economic, spatial and environmental aspects of growing geotourism in island Iceland [in:] V. Klímová, V. Žítek (eds.), 21st International Colloquium on Regional Sciences. Conference Proceedings 21, Kurdějov (Czech Republic) June 13-15, pp. 595-602.

Tomlison J., 1999. Globalization and culture. Chicago: University of Chicago Press.

Zelenka J. (ed.), 2008. Percepce krajiny a genius loci. Hradec Králové: Gaudeamus.

Žoncová M., 2018. Evaluation of the diversification of rural landscape in Slovakia after 1989 with a focus on the built-up area of municipalities: A case study of Podhájska municipality. Hungarian Geographical Bulletin, vol. 67, no. 2, pp. 143-158. https://doi.org/10.15201/hungeobull.67.2.3 